\title{
Introduction of temporal integration in fourth year MBBS curriculum; Students' experience
}

\author{
Rameen Shahid ${ }^{1}$, \\ Sumera Badar Ehsan ${ }^{2}$, Muhammad Nawaz ${ }^{3}$
}

\begin{abstract}
Objectives: Rapid innovations in medical science have necessitated the development of an advanced medical curriculum. Taking a step towards this, a temporal integrated system and clinic-pathological conferences themes were introduced in a public sector medical university for fourth year MBBS. This study aims to assess students' perceptions regarding this change.

Methods: A cross sectional study was conducted in a public sector medical university from May 2019 to April 2020. A 17 item pre-validated questionnaire was distributed among all students twice, firstly after completion of first module and then again at the end of the academic year. Results were analyzed using SPSS 21.

Results: There were 265 and 176 participants in the first and second phase of the study respectively. Majority of the students agreed that it was easier to study a topic when temporally integrated. Most commonly reported advantage was better understanding and concept of the theme under study. Suggestions included revision of the schedule regarding allocation of time for different topics and implementation of this curriculum from first year MBBS.

Conclusion: A small step was taken to make improvements in an old traditional method. Students are adapting to this change as they responded positively to various aspects of this methodology. Continuous feedback, evaluation and amendments will help to improve its effectiveness.
\end{abstract}

KEYWORDS: Professional education, Curriculum, Learning.

doi: https://doi.org/10.12669/pjms.38.3.4732

How to cite this:

Shahid R, Ehsan SB, Nawaz M. Introduction of temporal integration in fourth year MBBS curriculum; Students' experience. Pak J Med Sci. 2022;38(3):487-491. doi: https://doi.org/10.12669/pjms.38.3.4732

This is an Open Access article distributed under the terms of the Creative Commons Attribution License (http://creativecommons.org/licenses/by/3.0), which permits unrestricted use, distribution, and reproduction in any medium, provided the original work is properly cited.

\section{INTRODUCTION}

1. Rameen Shahid, Final Year MBBS Student,

2. Dr. Sumera Badar Ehsan, Assistant Professor Medical Education,

3. Prof. Dr. Muhammad Nawaz, Department of Ophthalmology,

1-3: Faisalabad Medical University, Faisalabad, Pakistan.

Correspondence:

Rameen Shahid, Final Year MBBS, Faisalabad Medical University, Sargodha Road,

Faisalabad. Pakistan.

E-mail: rameensh45@gmail.com

* Received for Publication:

May 18, 2021

* Revision Received:

* Revision Accepted:
September 27, 2021

October 22, 2021
Rapid innovations in medical science have necessitated the development of a modern teaching curriculum. Globally, such measures have been taken in the form of problem based learning, integrated teaching and self-assisted learning. ${ }^{1}$ Integration is defined as "education that is organized in such a way that it cuts across subjectmatter lines, bringing together various aspects of the curriculum into meaningful association to focus upon broad areas of study". ${ }^{2}$ This way of teaching has been adopted and endorsed by academic councils and medical colleges all over the world. ${ }^{3-5}$

The process of integration is further elaborated into various steps including sharing, nesting and temporal coordination. Temporal coordination, 
also known as parallel or concurrent teaching, is the scheduling of a lectures in such a way that the same topic is discussed by various disciplines at the same time. ${ }^{6}$ For example, students will discuss the pathology of asthma during pathology lectures and its clinical symptoms, diagnosis and treatment during medicine lessons during the same day or week.

At present, majority of medical colleges in Pakistan are following the conventional method of teaching that has a discipline based approach towards the subjects being taught. Students are unable to co-relate the information of basic and clinical sciences together and their visions and perspectives of medical knowledge remains confined. Keeping in view the latest trends in medical teaching and bringing a slight change in a rigid traditional system, temporal integration strategy was planned for $4^{\text {th }}$ year with consensus of the relevant heads of department. A timetable was developed to place lectures of similar topics of various disciplines in the same day or week. For example, in week one, students learnt the pathology of atherosclerosis during pathology lectures while its clinical manifestation i.e. coronary artery disease was discussed during medicine lectures in the same week.

This study aims to explore students experience and perceptions about this pilot project so that things could be improved in future.

\section{METHODS}

Department heads and medical educationists held meetings to streamline the plan and themes were identified keeping in view the university exam outcomes. As Pathology, community medicine, Ophthalmology, ENT are the examining subjects so the main focus was given to them and medicine and surgical subjects were aligned with the main themes. Timetable for first module is shown in Table-I. Clinicopathological conference were planned in the same way in which students presented the cases which was followed by discussion. It was run for the academic year 201920. A total of four modules were planned and each module was of 9 weeks duration.

This cross sectional study was performed at Faisalabad Medical University from May 19 to April 20 to assess students' perceptions and thus the effectiveness of temporal integration. Ethical approval was taken on $10^{\text {th }}$ May' 19 (registration no. 904). A three sectioned questionnaire, using 5-point Likert scale responses and open feedback questions, was developed and piloted. To ensure maximum accuracy, data was collected at two points in time; firstly, at the completion of eight weeks i.e. after first assessment week and secondly at the end of the academic year.

The first phase was conducted at the end of first assessment week. The questionnaire was distributed to all students present in the lecture hall. A brief overview of the study and questionnaire was given. These students who agreed to participate in the study filled and returned the questionnaires.

Again in the second phase, the same questionnaire was distributed at the end of the academic year, that is, March 2020. Due to closure of the university because of the Covid-19 pandemic, the questionnaire was sent using google forms on various social media platforms to the students. Again, students were explained the purpose of the questionnaire. SPSS 21 was used for data analysis. Responses in the first and second phases were compared using the Wilcoxon signed-rank test.

\section{RESULTS}

During the first phase 265 students participated in the study, comprising of 179 (67.5\%) females

Table-I: Time Table of first module Nov-Dec 2019.

\begin{tabular}{|c|c|c|c|c|c|}
\hline Subject & Week 1 & Week $2 \mathcal{E} 3$ & Week 4 E 5 & Week 6 & Week 7 \\
\hline Pathology & $\begin{array}{l}\text { Blood vessel } \\
\text { disease }\end{array}$ & $\begin{array}{l}\text { Cardiac } \\
\text { pathologies }\end{array}$ & Respiratory pathologies & $\begin{array}{l}\text { CNS patholo- } \\
\text { gies }\end{array}$ & Breast lesion \\
\hline $\begin{array}{l}\text { Ophthalmol- } \\
\text { ogy }\end{array}$ & $\begin{array}{l}\text { Retinal vascular } \\
\text { diseases }\end{array}$ & IOP glaucoma & $\begin{array}{l}\text { Abnormalities of pupillary reflex } \\
\text { and visual pathway }\end{array}$ & $\begin{array}{l}\text { Papilledema, } \\
\text { optic atrophy }\end{array}$ & $\begin{array}{l}\text { Retinoblas- } \\
\text { toma }\end{array}$ \\
\hline $\begin{array}{l}\text { Otorhinolar- } \\
\text { yngology }\end{array}$ & $\begin{array}{l}\text { Nasal vascular } \\
\text { problems }\end{array}$ & Trachea, DNS & $\begin{array}{l}\text { Airway allergies, rhinitis, sinusi- } \\
\text { tis }\end{array}$ & $\begin{array}{l}\text { CSF rhinor- } \\
\text { rhea and } \\
\text { polyps }\end{array}$ & Nasal tumors \\
\hline $\begin{array}{l}\text { Community } \\
\text { Medicine }\end{array}$ & $\begin{array}{l}\text { Occupational } \\
\text { health }\end{array}$ & Demography & $\begin{array}{l}\text { Communicable and non-commu- } \\
\text { nicable diseases }\end{array}$ & $\begin{array}{l}\text { Environmen- } \\
\text { tal health }\end{array}$ & $\begin{array}{l}\text { Maternal and } \\
\text { child health }\end{array}$ \\
\hline
\end{tabular}


Table-II: Comparison of mean scores during first and second phases.

\begin{tabular}{|c|c|c|c|c|}
\hline & $\begin{array}{l}\text { Mean Score } \\
\text { (first phase) }\end{array}$ & $\begin{array}{l}\text { Means score } \\
\text { (second phase) }\end{array}$ & Z & Sig \\
\hline $\begin{array}{l}\text { Temporal coordination provides a better understanding } \\
\text { and concept of the topic }\end{array}$ & $3.2 \pm 1.25$ & $3.30 \pm 1.13$ & -.83 & 0.40 \\
\hline It stimulates students' interest in the subject & $3.00 \pm 1.10$ & $3.00 \pm 1.16$ & -.195 & 0.85 \\
\hline Promotes critical thinking & $2.93 \pm 1.05$ & $3.08 \pm 1.08$ & -.129 & 0.20 \\
\hline Helps in knowledge retention & $3.28 \pm 1.10$ & $2.96 \pm 1.18$ & -2.86 & 0.00 \\
\hline $\begin{array}{l}\text { Helps in developing differential diagnosis during ward and } \\
\text { out-patient classes }\end{array}$ & $2.94 \pm 1.22$ & $3.00 \pm 1.12$ & -.39 & 0.70 \\
\hline $\begin{array}{l}\text { It is easier to grasp a topic when it is taught simultaneously in } \\
\text { different subjects }\end{array}$ & $3.59 \pm 1.13$ & $3.40 \pm 1.67$ & -1.59 & 0.11 \\
\hline $\begin{array}{l}\text { Temporal coordination is better than the traditional method of } \\
\text { teaching? }\end{array}$ & $2.86 \pm 1.33$ & $2.84 \pm 1.28$ & -.071 & 0.94 \\
\hline Would you like to continue with this method in final year MBBS? & $2.56 \pm 1.53$ & $2.37 \pm 1.39$ & -1.23 & 0.22 \\
\hline CPC is helpful in attempting OSCEs & $2.39 \pm 1.16$ & $2.63 \pm 1.22$ & -1.83 & 0.07 \\
\hline $\begin{array}{l}\text { CPC is helpful in attempting long case during clinical } \\
\text { examinations }\end{array}$ & $2.72 \pm 1.21$ & $2.85 \pm 1.19$ & -1.01 & 0.31 \\
\hline $\begin{array}{l}\text { There should be separate CPC for fourth year students } \\
\text { that includes Eye and ENT. }\end{array}$ & $3.25 \pm 1.27$ & $3.21 \pm 1.20$ & -.33 & 0.74 \\
\hline Assessment week helps to study regularly & $1.80 \pm 1.18$ & $2.01 \pm 1.30$ & -1.66 & 0.10 \\
\hline It is helpful for preparation of annual professional examinations & $2.08 \pm 1.40$ & $2.10 \pm 1.22$ & -.55 & 0.59 \\
\hline
\end{tabular}

and $86(32.5 \%)$ males. In the second phase there were 176 respondents, 115 (65.3\%) females and 76 $(34.7 \%)$ males. These percentages are concurrent with the gender ratio of our study population i.e. all $4^{\text {th }}$ year MBBS students.

The overall response regarding the temporally integrated curriculum was positive. About $64.8 \%$ respondents in phase 1 and $56.5 \%$ students in phase 2 agreed that it was easier to study a theme when taught simultaneously in different subject lectures in the same day or week. Nearly $40 \%$ of participants in both phases agreed that it was better than the traditional method of teaching. The most agreed positive aspect was gaining better understanding and concept as indicated by $55.3 \%$ and $56.8 \%$ students in the first and second phase respectively. However, there were mixed opinions regarding continuation of integrated learning in final year. Except for the views on role of integrated teaching in knowledge retention, there was no significant difference in responses during phase 1 and phase 2. Points were awarded for each response on the Likert scale ( 1 = strongly disagree, $2=$ disagree, $3=$ neutral, $4=$ agree, $5=$ strongly agree). Mean scores are shown in Table-II.

Majority students were not in favor of assessment weeks and preferred a weekly, bimonthly or monthly test system. Popular responses are shown in Table-III and Table-IV. Lack of proper implementation of the timetable and skipping important concepts during lectures were the

Table-III: Open responses during first phase.

\begin{tabular}{|c|c|}
\hline Problems/Suggestions & Other benefits \\
\hline Regular tests should be taken $(50 / 105)$ & Relaxation period between assessments (12/105) \\
\hline Rushing through essential concepts during lectures $(18 / 105)$ & $\begin{array}{l}\text { Proper schedule allows us to plan activities } \\
\text { beforehand }(5 / 105)\end{array}$ \\
\hline \multicolumn{2}{|l|}{ Difficult to cover two months syllabus on 1 week $(11 / 105)$} \\
\hline \multicolumn{2}{|l|}{ Ensure actual implementation of integration (6/105) } \\
\hline More benefit if implemented from first year $(3 / 105)$ & \\
\hline
\end{tabular}


Table-IV: Open responses during second phase.

\begin{tabular}{ll}
\hline Problems/Suggestions & Other benefits \\
\hline Regular tests should be taken $(17 / 43)$ & $\begin{array}{l}\text { Proper schedule being implemented rather } \\
\text { than haphazard lectures }(4 / 43)\end{array}$ \\
Difficult to sit all tests in a single week $(7 / 43)$ & $\begin{array}{l}\text { Relaxation period between tests allows to spare } \\
\text { time for co-curricular activities }(3 / 43)\end{array}$ \\
Lack of proper implementation of schedule (5/43) & \\
Essential concepts not being covered $(4 / 43)$ & \\
Implement from $1^{\text {st }}$ year as it is difficult to adjust now $(3 / 43)$ & \\
\hline
\end{tabular}

common problems as reported by $11 \%$ and $9 \%$ of the participants respectively. Many students mentioned that this method would have been more beneficial if introduced from the beginning as they had difficulty adapting to it.

\section{DISCUSSION}

Medical teaching and curricula are evolving fast with new methodologies being piloted and adopted for effective learning. Unfortunately, medical schools in Pakistan lag much behind and have deficiencies that were eliminated elsewhere long ago. ${ }^{7}$ These include didactic lectures with learning in fragments. Furthermore, as a part of standardization, accreditation of medical schools by international bodies is becoming mandatory. Educational Committee for Foreign Medical Graduates USA has announced that by 2024, only graduates of accredited medical schools will be eligible for certification. ${ }^{8}$ This makes it necessary to take step by step measures in adopting an updated effective medical education system for our students to stand at par with rest of the world. These include introduction of new teaching elements such as problem based leaning etc.

Transforming medical education is a long and eventual process. Through integrated teaching, an effort has been made to set the ball rolling. Integrated teaching is considered an effective strategy to bring about coordination in teaching and learning activities. ${ }^{9}$ It has been adopted worldwide to bridge the gap between compartmentalized knowledge and develop a more holistic approach in learning. ${ }^{10-12}$ It also gives a better perception of learning environment and helps in knowledge retention. ${ }^{13,14} \mathrm{~A}$ study from a private sector medical university in Pakistan also reports students endorsing integrated teaching. ${ }^{15}$

Our study aimed to assess the perceptions of medical students regarding the new integrated teaching. This would help in improving the design and overcoming the flaws for a more studentcentered curriculum. ${ }^{16}$ Overall, there were mixed responses. Our study showed that almost 55\% believed that integrated teaching improved understanding and concept of the topic under study. This percentage is higher than a similar study in Rajasthan, India. ${ }^{17}$ However, other studies have reported more than $90 \%$ percent students agreeing to this statement. ${ }^{18,19}$ Score for 'promoting critical thinking' was less than that of a similar study conducted in India..$^{10}$ Almost $40 \%$ students preferred integrated teaching over traditional methods which mirrors the views of students in a similar study. ${ }^{20}$

Although $67 \%$ students in the first and 57\% students in the second phase felt that it was easier to grasp a topic, only $37 \%$ and $32 \%$ in the respective phases wanted to continue integrated teaching in next academic year. The reason for this gap can be explained by responses from the open feedback section. Many students found the assessment pattern tiresome and unsatisfactory. Students in other studies also expressed concerns regarding inability to cope with frequent assessment pattern. ${ }^{21,22}$ Some participants reported lack of actual integration of topics, rushing through syllabus contents and skipping important concepts during lectures which is also seen in other studies. ${ }^{23}$ Another view was that it was difficult to adapt to a new learning method and it would have been fruitful if introduced from first year.

Designing an integrated curriculum is a complex process and involves various challenges. ${ }^{14}$ Evaluation serves as a key tool to overcome the barriers as it will provide important insights and help make appropriate amendments. The concerns of students should be addressed which would pave the way to better outcomes. 
Limitations: Our study also had some limitations. It was based on findings from a single center. Moreover, feedback from faculty was not taken.

\section{CONCLUSION}

Integrated curriculum has its own benefits and challenges. It is a gradual process and its success relies on continuous feedback and modifications. Public sector challenges are unique in so many aspects as changes in decades old curriculum are not readily accepted by faculty and students. Moreover, resources are limited. It is a small effort to bring a minute change so that the path towards integration could be paved with ease.

\section{Conflict of interest: None.}

\section{Grant Support E Financial Disclosures: None.}

\section{REFERENCES}

1. Smith SR. Toward an integrated medical curriculum. Med Health R I. 2005;88:258-256.

2. Shoemaker BJE. Integrative Education: A Curriculum for the Twenty-First Century. Oregon School Study Council Bulletin. 1989;33(2):1-46.

3. General Medical Council. Tomorrow's doctors: Recommendations on undergraduate medical education. London: GMC, 1993.

4. Curriculum implementation support programme. Medical Council of India. 2012

5. Ganguly P, Yaqinuddin A, Al-Kattan W, Kemahli S, AlKattan K. Medical education dilemma: How can we best accommodate basic sciences in a curriculum for $21^{\text {st }}$ century medical students? Can J Physiol Pharmacol. 2019;97:293-296. doi: 10.1139/cjpp-2018-0428

6. Harden RM. The integration ladder: a tool for curriculum planning and evaluation. Med Ed. 2000;34:551-557. doi: 10.1046/j.1365-2923.2000.00697.x

7. Amin Z. Burdick WP, Supe A, Singh T. Relevance of the Flexner Report to Contemporary Medical Education in South Asia. Acad Med. 2010;85:333-339. doi: 10.1097/ ACM.0b013e3181c874cb

8. Shiffer C, Boulet JR, Cover L, Pinsky, W. Advancing the Quality of Medical Education Worldwide: ECFMG's 2023 Medical School Accreditation Requirement. J Med Regul. 2019;105:8-16. doi. 10.30770/2572-1852-105.4.8.

9. Pring R. Curriculum integration. In: Hooper R, Editor. The Curriculum: Context Design and Development Education. Edinburgh: Oliver \& Boyd. 1970;265-272.

10. Basu M, Das P, Chowdhury G. Introducing integrated teaching and comparison with traditional teaching in undergraduate medical curriculum: A pilot study. Med J DY Patil Univ. 2015;8:431-438. doi: 10.4103/09752870.160778

11. Tsinopoulos IT, Symeonidis C, Tsaousis KT, Mataftsi A, Chalvatzis N, Tzamalis A, et al. Contribution of integrated teaching in the improvement of an undergraduate ophthalmology curriculum. Adv Med Educ Pract. 2014;5:433-437 doi: 10.2147/AMEP.S71759
12. Rooholamini A, Amini M, Bazrafkan L, Dehgani MR, Esmaeilzadeh Z, Nabeiei P, et al. Program evaluation of an Integrated Basic Science Medical Curriculum in Shiraz Medical School, Using CIPP Evaluation Model. J Adv Med Educ Prof. 2017;5:148-154.

13. Quintero GA, Vergel J, Arredondo M, Ariza MC, Gomez P, Barrios AMP. Integrated Medical Curriculum: Advantages and Disadvantages. J Med Educ Curric Dev. 2016;3:133137. doi: 10.4137/JMECD.S18920

14. Muller JH, Jain S, Loeser H, Irby DM. Lessons learned about integrating a medical school curriculum: perceptions of students, faculty and curriculum leaders. Med Educ. 2008;42:778-785. doi: 10.1111/j.1365-2923.2008.03110.x

15. Reza Z, Jadoon HK, Danish SH, Fahad Kazmi SA, Ahmed F. Student's opinion regarding teaching methods: A survey amongst MBBS and BDS students of a private Medical University in Karachi - Short Communication. J Pak Med Assoc. 2018;68:1281-1284.

16. McLean M, Gibbs T. Twelve tips to designing and implementing a learner-centred curriculum: Prevention is better than cure. Med Teach. 2010;32:225-230. doi: $10.3109 / 01421591003621663$

17. Ambwani S, Vegada B, Sidhu R, Charan J. Impact of integrated teaching sessions for comprehensive learning and rational pharmacotherapeutics for medical undergraduates. Int J App Basic Med Res. 2017;7:S57-S61. doi: 10.4103/ijabmr.IJABMR_130_17

18. Shah V, Jain UJ. The effectiveness of integrated teaching over traditional teaching in third MBBS students. Int J Med Sci Public Health. 2016;5:1430-1432. doi: 10.5455/ ijmsph.2016.22052016505

19. Rehman R, Iqbal A, Syed S, Kamran A. Evaluation of integrated learning program of undergraduate medical students. Pak J Physiol. 2011:7:37-41

20. Kumari K, Mysorekar VV, Raja S. Student's perception about integrated teaching in an undergraduate medical curriculum. J Clin Diagn Res. 2011;5(Suppl-1):1256-1259.

21. Pedersen S, Williams D. A comparison of assessment practices and their effects on learning and motivation in a student centered learning environment. J Educ Multimedia Hypermedia. 2004;13(3):283-306.

22. Aziz A, Mahboob U, Sethi A. What problems make students struggle during their undergraduate medical education? A qualitative exploratory study. Pak J Med Sci. 2020;36:1020-1024. doi: 10.12669/pjms.36.5.2267.

23. Arain SA, Kumar S, Yaqinuddin A, Meo SA. Vertical integration of head, neck, and special senses module in undergraduate medical curriculum. Adv Physiol Educ. 2020;44:344-349. doi: 10.1152/advan.00173.2019

\section{Authors' Contribution:}

RS did literature search, data analysis, data interpretation and manuscript writing and is responsible for accuracy and integrity of the work. SBE designed the study and questionnaire.

MN did study design, data acquisition and revised the manuscript. 